\title{
Pemberian Pendidikan Kesehatan Reproduksi Berpengaruh Terhadap Tingkat Pengetahuan Tentang Seks Bebas pada Remaja Kelas X dan XI di SMK Muhammadiyah II Bantul
}

\author{
Dian Savitri ${ }^{1}$, Kirnantoro², Siti Nurunniyah ${ }^{3}$ \\ ${ }^{1,3}$ Sekolah Tinggi Ilmu Kesehatan Alma Ata Yogyakarta \\ Jalan Ringroad Barat Daya No 1 Tamantirto, Kasihan, Bantul, Yogyakarta \\ ${ }^{2}$ Program Studi Keperawatan Politeknik Kesehatan Kementrian Kesehatan Yogyakarta \\ Jalan Tata Bumi No. 3, Sleman, Daerah Istimewa Yogyakarta
}

\begin{abstract}
Abstrak
Data Pusat Studi Seksualitas (PSS) PKBI DIY tahun 2008 menemukan fakta bahwa remaja melakukan perilaku seksual berpelukan dalam pacaran 62,1\%, bergandengan tangan 60,5\%, berciuman bibir 59\%, dan saling meraba $60 \%$. Perilaku seksual beresiko lainnya yang dilakukan remaja adalah membaca buku/majalah porno yaitu sebesar 63,7\% menonton blue film 46,7\% dan masturbasi mencapai 30,2\%. Tujuan penelitian untuk mengetahui tingkat pengetahuan sebelum dan sesudah intervensi dan mengetahui pengaruh pemberian pendidikan kesehatan reproduksi terhadap tingkat pengetahuan tentang seks bebas. Jenis Penelitian ini adalah penelitian praeksperimen dengan rancangan one group pretest posttest. Sampel yang digunakan yakni 43 siswa. Instrumen yang digunakan adalah kuesioner tertutup dengan menggunakan skala ordinal. Hasil penelitian menunjukkan tingkat pengetahuan responden sebelum intervensi adalah tinggi sebanyak 27 responden (62,8\%), sedang sebanyak 10 responden $(23,3 \%)$ dan rendah sebanyak 6 responden $(14,0 \%)$. Tingkat pengetahuan responden setelah intervensi adalah tinggi sebanyak 35 responden $(81,4 \%)$, sedang sebanyak 8 responden $(18,6 \%)$ dan rendah 0 responden (0\%). Dan hasil penelitian menunjukkan ada pengaruh yang signifikan antara pemberian pendidikan kesehatan reproduksi terhadap tingkat pengetahuan tentang seks bebas pada remaja dengan nilai $z=-3,960$ dan nilai $p$-value $=0,000$. Kesimpulan tingkat pengetahuan responden sebelum intervensi tinggi dengan persentase $62,8 \%$ dan tingkat pengetahuan setelah intervensi tinggi dengan persentase 81,4\%. Ada pengaruh yang signifikan pada $p$-value=0,000 dan z=-3,960.
\end{abstract}

Kata Kunci: pendidikan kesehatan reproduksi, tingkat pengetahuan, seks bebas

Info Artikel:

Artikel dikirim pada 7 Januari 2013

Artikel diterima pada 7 Januari 2013

\section{PENDAHULUAN}

Remaja adalah suatu masa dimana individu berkembang dari saat pertama kali ia menunjukkan tanda-tanda seksual sekundernya sampai saat ia mencapai kematangan seksual, individu mengalami perkembangan psikologi dan pola identifikasi dari kanak-kanak sampai dewasa(1). Pada usia 1019 tahun kondisi emosional remaja masih labil dan rentan terhadap pengaruh apapun, sehingga pada remaja sering terjadi perilaku seks bebas(2). Seks bebas berkembang dari suatu budaya Barat yang menekankan pada kebebasan, seperti bebas melakukan hubungan seksual sebelum menikah, bebas berganti-ganti pasangan, dan bebas melakukan hubungan seksual usia dini(3).
Responden wanita dan pria berusia 1519 tahun yang menyatakan bahwa gairah seks meningkat adalah tanda perubahan fisik pada remaja. Pengetahuan remaja umur 15-24 tahun tentang masa subur hanya $26 \%$ wanita dan $21 \%$ pria yang memberi jawaban benar tentang kesempatan terbesar seorang wanita menjadi hamil pada pertengahan siklus haid. Sebesar $74,1 \%$ wanita dan $70 \%$ pria usia $15-19$ tahun tidak mengetahui gejala Infeksi Menular Seksual(4). $\mathrm{Hal}$ ini memberikan bukti rendahnya pengetahuan remaja tentang kesehatan reproduksi remaja.

Data Pusat Studi Seksualitas (PSS) PKBI DIY tahun 2008 menemukan fakta bahwa remaja melakukan perilaku seksual berpelukan dalam pacaran $62,1 \%$, bergandengan tangan $60,5 \%$, 
berciuman bibir $59 \%$, dan saling meraba $60 \%$. Perilaku seksual beresiko lainnya yang dilakukan remaja adalah membaca buku/majalah porno yaitu sebesar $63,7 \%$ menonton blue film $46,7 \%$ dan masturbasi mencapai 30,2\%(5).

Kabupaten Bantul provinsi DIY, angka pernikahan dini usia di bawah 20 tahun tergolong tinggi. Dalam satu semester tahun 2009, jumlah perkara yang meminta dispensi kawin muda pada Pengadilan Agama (PA) Kabupaten Bantul mencapai 65 kasus. Jumlah remaja yang berusia 15 sampai 19 tahun di kabupaten Bantul terdapat 77.386 remaja dan pada tahun 2009 terdapat 1365 orang yang hamil di bawah 20 tahun(6). Tingginya angka pernikahan pada usia muda dan banyaknya jumlah ibu hamil di bawah 20 tahun tidak dapat dipungkiri bahwa sebagian dikarenakan kehamilan pranikah.

Menurut Pangkahila, kurangnya pemahaman tentang perilaku seksual pada masa remaja amat merugikan bagi remaja itu sendiri termasuk keluarganya, sebab pada masa ini remaja mengalami perkembangan yang penting yaitu kognitif, emosi, sosial dan seksual. Perkembangan ini akan berlangsung mulai sekitar 12 sampai 20 tahun. Kurangnya pemahaman tersebut disebabkan oleh berbagai faktor antara lain: adat istiadat, budaya, agama, dan kurangnya informasi dari sumber yang benar. Hal ini akan mengakibatkan berbagai dampak yang justru amat merugikan kelompok remaja dan keluarganya(7).

Promosi kesehatan reproduksi pada remaja sering dikonotasikan sebagai pendidikan seks di mana sebagian besar masyarakat di Indonesia masih mentabukan hal ini. Bahkan ada lembaga pendidikan formal setingkat sekolah menengah yang masih ragu untuk melaksanakan penyuluhan kesehatan reproduksi bagi siswanya. Sementara itu, masa remaja adalah fase pertumbuhan dan perkembangan saat individu mencapai usia 10-19 tahun. Dalam rentang waktu ini terjadi pertumbuhan fisik yang cepat, termasuk pertumbuhan serta kematangan dari fungsi organ reproduksi. Bila tidak didasari dengan pengetahuan yang cukup, mencoba hal baru yang berhubungan dengan kesehatan reproduksi bisa memberikan dampak yang akan menghancurkan masa depan remaja dan keluarga.

Dari hasil studi pendahuluan di SMK Muhammadiyah II Bantul pada tanggal 21 Februari 2012 didapatkan informasi bahwa di sekolah tersebut tidak ada mata pelajaran yang berkaitan dengan kesehatan reproduksi. Pelajaran kesehatan reproduksi hanya diperoleh dari penyuluhan BKKBN yang diadakan setahun sekali, sehingga pengetahuan siswa mengenai kesehatan reproduksi terbatas. Selama 3 tahun terakhir sekolah ini sudah mengeluarkan 5 siswi yang hamil akibat seks bebas. Jumlah siswa dan siswi kelas $X$ dan XI SMK Muhammadiyah II Bantul adalah 289 siswa yang terdiri dari 9 kelas. Dari hasil wawancara 10 siswa di SMK Muhammadiyah II Bantul menambahkan bahwa siswa mendapatkan informasi mengenai kesehatan reproduksi dan seks bebas yang didapat dari keluarga, teman dan orang tua sebanyak 7 siswa dan yang didapat dari internet dan buku sebanyak 3 siswa. Setelah ditanya mengenai faktor yang mempengaruhi perilaku seks bebas adalah pengaruh teman dan lingkungan sekitar (2 siswa), kurangnya informasi mengenai seks bebas (4 siswa), kurangnya perhatian dari orang tua atau anak yang mengalami broken home (4 siswa). Ketika ditanya oleh peneliti apakah aborsi dapat menyebabkan kematian, 6 siswa menjawab iya dan 4 siswa lainnya mengatakan tidak. Kemudian setelah ditanya tentang dampak seks bebas 9 siswa menjawab kehamilan yang tidak diinginkan dan 1 siswa menjawab dikucilkan oleh keluarga dan teman.

Secara umum tujuan penelitian untuk mengetahui pengaruh pemberian pendidikan kesehatan reproduksi terhadap tingkat pengetahuan tentang seks bebas pada remaja kelas $X$ dan XI di SMK Muhammadiyah II Bantul. Secara khusus untuk mengetahui tingkat pengetahuan tentang seks bebas pada remaja sebelum mendapat pendidikan kesehatan reproduksi dan untuk mengetahui tingkat pengetahuan tentang seks bebas pada remaja sesudah mendapat pendidikan kesehatan reproduksi.

\section{BAHAN DAN METODE}

Jenis Penelitian ini adalah penelitian pra eksperimen dengan rancangan one group pretest posttest. Rancangan ini tidak menggunakan kelompok pembanding (control), tetapi paling tidak sudah dilakukan observasi pertama (pretest) yang memungkinkan menguji perubahan-perubahan yang terjadi setelah adanya eksperimen (program), dan dilakukan pengambilan data akhir (posttest)(9). Populasi dalam penelitian ini adalah siswa-siswi kelas X dan XI SMK Muhammadiyah II Bantul yang berjumlah 289 siswa. Teknik sampling penelitian ini dilakukan dengan teknik random sampling, setiap populasi mempunyai kesempatan yang sama untuk dipilih sebagai sampel. Sampel yang digunakan merupakan perwakilan dari setiap kelas $\mathrm{X}$ dan $\mathrm{XI}$ yang berjumlah 9 kelas yang diambil adalah 43 siswa. Penelitian ini dilakukan di SMK Muhammdiyah II Bantu pada tanggal 12 Mei 2012 untuk pretest dan 
15 Mei 2012 untuk posttest. Instrumen penelitian adalah kuesioner yang berisi tentang pertanyaan dan pilihan jawaban yang sudah disediakan dalam bentuk pilihan benar atau salah. Kuesioner sudah dilakukan uji validitas pada tanggal 18 April 2012 di SMK Nasional Bantul dengan jumlah 35 pertanyaan. Hasil dari uji reliabilitas dengan menggunakan rumus spearman brown adalah 0,767 . Sehingga $r$ hitung $>r$ tabel maka dapat disimpulkan instrumen tersebut reliabel dan dapat digunakan untuk penelitian. Dalam penelitian ini yang merupakan variabel independen adalah pemberian pendidikan kesehatan reproduksi. Variabel dependen dalam penelitian ini adalah pengetahuan remaja tentang seks bebas.

\section{HASIL DAN BAHASAN}

Tingkat Pengetahuan tentang Seks Bebas pada Remaja di SMK Muhammadiyah 2 Bantul Sebelum Dilakukan Penyuluhan

Distribusi frekuensi tingkat pengetahuan tentang seks bebas pada remaja di SMK Muhammadiyah 2 Bantul sebelum diberikan penyuluhan disajikan pada Tabel 1.

Tabel 1. Distribusi Frekuensi Tingkat Pengetahuan tentang Seks Bebas pada Remaja di SMK Muhammadiyah 2 Bantul Sebelum Diberikan Penyuluhan

\begin{tabular}{lcc}
\hline Tingkat Pengetahuan & $\mathbf{f}$ & \% \\
\hline Rendah & 6 & 14,0 \\
Sedang & 10 & 23,3 \\
Tinggi & 27 & 62,8 \\
Total & 43 & 100 \\
\hline
\end{tabular}

Sumber: Data Primer Tahun 2012

Berdasarkan Tabel 1 merupakan tabel tingkat pengetahuan responden tentang seks bebas pada remaja sebelum diberikan intervensi dimana sebagian besar responden tergolong memiliki tingkat pengetahuan tinggi sebanyak 27 responden $(62,8 \%)$, kemudian diikuti tingkat pengetahuan sedang sebanyak 10 responden $(23,3 \%)$ dan hanya 6 siswi $(14,0 \%)$ tergolong rendah.

Tingkat Pengetahuan tentang Seks Bebas pada Remaja di SMK Muhammadiyah 2 Bantul Setelah Dilakukan Penyuluhan

Distribusi frekuensi tingkat pengetahuan tentang seks bebas pada remaja di SMK Muhammadiyah 2 Bantul setelah diberikan penyuluhan disajikan pada Tabel 2.

Berdasarkan Tabel 2 menunjukkan tingkat pengetahuan tentang seks bebas setelah dilakukan
Tabel 2. Distribusi Frekuensi Tingkat Pengetahuan tentang Seks Bebas pada Remaja di SMK Muhammadiyah 2 Bantul Setelah Dilakukan Penyuluhan

\begin{tabular}{lcc}
\hline Tingkat Pengetahuan & $\mathbf{f}$ & $\%$ \\
\hline Rendah & 0 & 0 \\
Sedang & 8 & 18,6 \\
Tinggi & 35 & 81,4 \\
Total & 43 & 100 \\
\hline
\end{tabular}

Sumber: Data Primer Tahun 2012

intervensi. Berdasarkan tabel tersebut, tingkat pengetahuan didominasi oleh tingkat pengetahuan tinggi sebanyak 35 siswa $(81,4 \%)$, kategori sedang 8 siswa $(18,6 \%)$ dan kategori rendah 0 responden $(0 \%)$.

Tingkat Pengetahuan tentang Seks Bebas pada Remaja Di SMK Muhammadiyah 2 Bantul Sebelum dan Setelah Dilakukan Penyuluhan

Perbandingan tingkat pengetahuan tentang seks bebas pada remaja di SMK Muhammadiyah 2 Bantul sebelum dan setelah diberikan penyuluhan disajikan pada Tabel 3.

Tabel 3. Distribusi Frekuensi Tingkat Pengetahuan tentang Seks Bebas pada Remaja di SMK Muhammadiyah 2 Bantul Sebelum dan Setelah Dilakukan Penyuluhan

\begin{tabular}{lccc}
\hline \multicolumn{1}{c}{$\begin{array}{c}\text { Tingkat } \\
\text { Pengetahuan }\end{array}$} & Pretest & Posttest & Keterangan \\
\hline Rendah & 6 & 0 & Ada Kenaikan \\
Sedang & 10 & 8 & Ada Kenaikan \\
Tinggi & 27 & 35 & Ada Kenaikan \\
Total & 43 & 43 & \\
\hline
\end{tabular}

Sumber: Data Primer Tahun 2012

Berdasarkan Tabel 3 menunjukkan tingkat pengetahuan tentang seks bebas setelah diberikan intervensi pada responden mengalami kenaikan. Berdasarkan tabel tersebut, tingkat pengetahuan tinggi pada saat pretest sebanyak 27 responden dan pada saat posttest menjadi 35 responden. Kategori sedang pada saat pretest sebanyak 10 responden dan posttest menjadi 8 responden, dan kategori rendah pada saat pretest sebanyak 6 responden dan pada saat posttest menjadi 0 responden.

Pengaruh Pemberian Pendidikan Kesehatan Reproduksi terhadap Tingkat Pengetahuan tentang Seks Bebas pada Remaja di SMK Muhammadiyah 2 Bantul

Untuk mengetahui pengaruh penyuluhan terhadap tingkat pengetahuan remaja digunakan analisis uji wilcoxon seperti pada Tabel 4. 
Tabel 4. Perbedaan Rerata Tingkat Pengetahuan Tentang Seks Bebas pada Remaja di SMK

Muhammadiyah 2 Bantul Sebelum dan Setelah diberikan Penyuluhan

\begin{tabular}{lccc}
\hline $\begin{array}{c}\text { Tingkat } \\
\text { Pengetahuan }\end{array}$ & Mean & $\begin{array}{c}\text { Mean } \\
\text { Difference }\end{array}$ & SD \\
\hline Pretest & 24,19 & 2,30 & 4,48 \\
Posttest & 26,49 & 2,30 & 2,84 \\
\hline
\end{tabular}

Sumber: Data Primer Tahun 2012

Berdasarkan Tabel 4 menjelaskan tentang perbedaan rerata tingkat pengetahuan tentang seks bebas sebelum dan setelah intervensi, dimana data tersebut menjelaskan bahwa perbedaan rerata antara pretest dan posttest adalah 2,30 , sedang perbedaan standar deviasi sebesar 1,64.

Tabel 5. Pengaruh penyuluhan terhadap Tingkat Pengetahuan Tentang Seks Bebas pada Remaja di SMK Muhammadiyah 2 Bantul

\begin{tabular}{|c|c|c|c|c|c|c|c|c|}
\hline \multirow{3}{*}{ Pretest } & \multicolumn{6}{|c|}{ Posttest } & \multirow{3}{*}{$z$} & \multirow{3}{*}{ p-value } \\
\hline & \multicolumn{2}{|c|}{ Sedang } & \multicolumn{2}{|c|}{ Tinggi } & \multicolumn{2}{|c|}{ Total } & & \\
\hline & $f$ & $\%$ & $f$ & $\%$ & $f$ & $\%$ & & \\
\hline Rendah & 1 & 2,3 & 5 & 11,6 & 6 & 13,9 & $-3,960$ & 0,000 \\
\hline Sedang & 3 & 7,0 & 7 & 16,3 & 10 & 23,3 & & \\
\hline Tinggi & 4 & 9,3 & 23 & 53,5 & 27 & 62,8 & & \\
\hline Total & 8 & 18,6 & 35 & 81,4 & 43 & 100 & & \\
\hline
\end{tabular}

Sumber: Data Primer Tahun 2012

Berdasarkan Tabel 5 menjelaskan tentang hasil analisis uji wilcoxon. Data tersebut menunjukkan nilai Z sebesar $-3,960$. Bila taraf kesalahan 0,05 maka harga $z$ tabel $=1,64$. Harga $z$ hitung $>z$ tabel (harga (-) tidak diperhitungkan karena harga mutlak), dengan demikian Ha diterima. Didapatkan juga nilai $p$-value 0,000 . Maka $p$-value $<0,05$. Sehingga dapat dikatakan bahwa ada pengaruh yang signifikan antara sebelum dan sesudah pemberian pendidikan kesehatan reproduksi terhadap tingkat pengetahuan tentang seks bebas pada remaja di SMK Muhammadiyah 2 Bantul.

\section{Tingkat Pengetahuan Tentang Seks Bebas pada Remaja di SMK Muhammadiyah 2 Bantul Sebelum Penyuluhan}

Penelitian ini dilakukan untuk mengetahui tingkat pengetahuan tentang seks bebas pada remaja di SMK Muhammadiyah 2 Bantul dengan diberikan intervensi berupa pemberian pendidikan kesehatan reproduksi. Sampel yang diambil pada penelitian ini sebanyak 43 siswa. Sebelum diberikannya intervensi, dari seluruh siswa yang dijadikan sampel, mayoritas siswa berpengetahuan tinggi dengan persentase $62,8 \%$, sedangkan untuk siswa berpengetahuan rendah sebesar $14,0 \%$.
Data tersebut menunjukkan bahwa mayoritas siswa sudah mengetahui tentang kesehatan reproduksi. Sebelum diberikan intervensi, mayoritas siswa sudah dibekali wawasan tentang kesehatan reproduksi. Pengetahuan tersebut diperoleh dari berbagai sumber, seperti misalnya melalui internet, buku, tenaga kesehatan dan Iain-lain. Tetapi pengetahuan tersebut hanya pada tingkatan tahu. Sedangkan untuk tingkatan sintesis atau bahkan evaluasi diperlukan informasi-informasi yang lebih detail sebagai dasar pengetahuan seks bebas.

Hal ini seperti sejalan dengan pendapat dari Notoatmodjo yang menyatakan bahwa pengetahuan itu sendiri banyak dipengaruhi oleh beberapa faktor, salah satunya yaitu pendidikan formal(10). Sehingga pengetahuan sangat erat hubungannya dengan pendidikan yang tinggi, maka orang tersebut akan semakin luas pula pengetahuannya. Akan tetapi bukan berarti seseorang yang berpendidikan rendah, mutlak berpengetahuan rendah pula. Hal ini mengingat bahwa, peningkatan pengetahuan tidak mutlak di peroleh dari pendidikan non formal. Pengetahuan seseorang tentang suatu obyek mengandung dua aspek yaitu posisif dan negatif. Kedua aspek ilmiah yang pada akhirnya akan menentukan sikap seseorang tentang suatu obyek tertentu. Semakin banyak aspek positif dan obyek yang diketahui, maka akan menimbulkan sikap makin positif terhadap obyek tertentu.

Pada dasarnya tingkat pengetahuan meliputi tahu, paham, penerapan, analisa, sintesa, dan evaluasi. Menurut Nurhidayah memberikan pengertian tentang tingkat kemampuan tahu yaitu kemampuan responden untuk menghafal, mengingat, mendefinisi, mengenali, atau mengidentifikasi informasi tentang fakta, peraturan prinsip, kondisi, dan syarat yang disajikan dalam pengajaran(11). Kecilnya persentase tingkat pengetahuan kesehatan reproduksi kategori kurang dari penelitian ini sebelum dilakukan intervensi menunjukkan bahwa informasi tentang kesehatan reproduksi sudah diketahui melalui berbagai sumber walaupun belum pernah dilakukan intervensi sebelumnya.

Notoatmodjo mendefinisikan penyuluhan kesehatan merupakan upaya merubah perilaku individu, keluarga, kelompok ataupun masyarakat dalam pencapaian tujuan kesehatan yang optimal(10). Sehingga individu tidak hanya tahu tentang kesehatan reproduksi, tetapi lebih dari itu, intervensi yang diberikan diharapkan dapat membentuk perilaku sehat sehingga dapat menurunkan angka kesakitan dan kematian.

Menurut Notoatmodjo pengetahuan seseorang dapat diperoleh dari pengalaman yang berasal dari 
media massa, media elektronik, buku, petugas kesehatan, orang tua, guru, saudara, teman dan sebagainya(12). Pengetahuan ini dapat berbentuk keyakinan tertentu, sehingga seseorang dapat berperilaku sesuai keinginan sebagai hasil proses pengaaruh pengideraan terhadap obyek. Ada banyak cara yang digunakan untuk memberikan informasi dalam rangka peningkatan pengetahuan khususnya tentang pengetahuan kesehatan reproduksi. Salah satu metode yang sering digunakan dalam ilmu kesehatan adalah dengan metode penyuluhan.

\section{Tingkat Pengetahuan tentang Perilaku Seks Bebas pada Remaja Di SMK Muhammadiyah 2 Bantul Setelah Penyuluhan}

Hasil penelitian diketahui bahwa pengetahuan siswa tentang kesehatan reproduksi setelah diberikan intervensi, siswa yang berpengetahuan tinggi menjadi meningkat dengan persentase sebesar $81,4 \%$. Hal ini menunjukkan respon responden terhadap pendidikan kesehatan reproduksi cukup tinggi. Sedangkan tingkat pengetahuan yang tergolong rendah menjadi tidak ada.

Hasil penelitian dengan memberikan intervensi berupa penyuluhan kesehatan reproduksi dapat merubah pengetahuan, sikap dan perilaku kesehatan, hal ini sesuai dengan penelitian yang dilakukan oleh Pasaribu dalam tesisnya yang berjudul "Perbandingan Penyuluhan Kesehatan Metode Ceramah Tanya Jawab dengan Penyuluhan Kesehatan Menggunakan Buku Kecacingan dalam Mencegah Reinfeksi Ascaris lumbricoides pada Anak Sekolah Dasar", dimana terjadi peningkatan pengetahuan setelah dilakukan penyuluhan pada kedua metode tersebut(13).

Seperti yang telah diketahui bahwa pendidikan kesehatan reproduksi ditujukan untuk menggugah kesadaran, memberikan atau meningkatkan pengetahuan. Pendidikan kesehatan ini merupakan proses pendidikan yang tidak terlepas dari proses belajar. Ketika pengetahuan atau pemahaman remaja tentang kesehatan reproduksi tinggi, dengan sendirinya akan mencegah terjadinya penyimpanganpenyimpangan seks bebas. Perilaku kesehatan reproduksi perlu ditumbuh kembangkan dengan peningkatan pengetahuan tentang kesehatan reproduksi itu sendiri. Masalah inilah yang menjadikan motivasi tersendiri bagi siswi SMK Muhammadiyah 2 Bantul dengan ditunjukkan sikap terhadap intervensi yang dilakukan peneliti, sehingga hasil yang diperoleh peningkatan pengetahuan siswi tersebut.

Informasi yang didapat responden tentang kesehatan reproduksi cukup tinggi. Pada remaja SMA rata-rata sudah mendapatkan informasi tentang alat reproduksi melalui mata ajar disekolahnya, yang terdapat pada mata ajar biologi. Saat duduk di bangku SMP pun remaja sudah mendapatkan sedikit pelajaran mengenai reproduksi manusia pada mata ajar biologi. Banyaknya media pemberian informasi membuat remaja semakin mudah memahami intervensi dalam penelitian ini, sehingga hasil yang diterima $81,4 \%$ siswa berpengetahuan tinggi.

\section{Pengaruh Penyuluhan terhadap Tingkat Pengetahuan Seks Bebas pada Remaja Di SMK Muhammadiyah 2 Bantul}

Pengaruh penyuluhan terhadap tingkat pengetahuan seks bebas dapat diketahui dengan menggunakan uji wilcoxon. Hasil analisis diperoleh adanya pengaruh yang signifikan $(p=0,000)$ pemberian pendidikan reproduksi kesehatan terhadap tingkat pengetahuan seks bebas pada remaja di SMK Muhammadiyah 2 Bantul.

Pemberian pendidikan kesehatan reproduksi berpengaruh terhadap tingkat pengetahuan tentang perilaku seks bebas. Jika dilihat nilai perbedaan ratarata, nilai rata-rata posttest lebih tinggi dibandingkan dengan pretest, hal ini menunjukkan adanya peningkatan pengetahuan kearah yang positif, artinya tingkat pengetahuan tentang perilaku seks bebas menjadi lebih baik setelah diberi intervensi. Dengan demikian, intervensi yang diberikan berhasil meningkatkan pengetahuan remaja di SMK Muhammadiyah 2 Bantul tentang seks bebas. Hasil penelitian ini berbeda dengan hasil penelitian yang dilakukan oleh Fayana dengan judul hubungan pemberiaan pendidikan seks (pre menarche) oleh orang tua terhadap tingkat pengetahuan remaja putri tentang menarche di SD Muhammadiyah Suronatan, dimana hasil penelitiannya menyatakan tidak ada hubungan yang bermakna antara pemberian pendidikan seks oleh orang tua terhadap tingkat pengetahuan remaja tentang menarche(14).

Penelitian Nisma memperkuat hasil penelitian ini dengan hasil yang menunjukkan adanya pengaruh penyampaian pendidikan kesehatan reproduksi oleh kelompok sebaya terhadap pengetahuan kesehatan remaja di SMP Negeri 2 Kasihan Bantul Yogyakarta(14).

Menurut Notoatmodjo, metode penyuluhan kesehatan pada dasarnya merupakan pendekatan yang digunakan dalam proses pendidikan untuk menyampaikan pesan kepada sasaran penyuluhan kesehatan, yaitu seperti individu, kelompok, keluarga dan masyarakat. Dalam penyampaian informasi yang ingin disampaikan, dapat dilakukan dengan menggunakan media sebagai sarana penyampaian pesan atau informasi(10). Alat atau sarana yang mudah digunakan dan dipahami oleh penyuluh maupun obyek sasaran merupakan nilai 
tambah tersendiri bagi keberhasilan atau efektifnya penyuluhan.

\section{SIMPULAN DAN SARAN}

Berdasarkan hasil penelitian dan pembahasan dapat disimpulkan bahwa tingkat pengetahuan tentang seks bebas pada remaja sebelum diberi pendidikan kesehatan reproduksi termasuk kategori tinggi dengan persentase $62,8 \%$, tingkat pengetahuan tentang seks bebas pada remaja setelah diberi pendidikan kesehatan reproduksi termasuk kategori tinggi dengan persentase $81,4 \%$, ada pengaruh yang signifikan pada $(p=0,000)$ dan nilai $z=-3,960$ antara pemberian pendidikan kesehatan reproduksi terhadap tingkat pengetahuan tentang seks bebas pada remaja di SMK Muhammadiyah 2 Bantul.

Penelitian ini hendaknya digunakan sebagai tambahan literatur untuk ilmu kebidanan mengenai pengetahuan remaja tentang seks bebas. Bagi Siswa SMK Muhammadiyah 2 Bantul penyuluhan kesehatan mengenai kesehatan reproduksi menunjukkan adanya peningkatan pengetahuan, sehingga diharapkan kepada siswa dapat mengaplikasikan ilmu yang didapat dalam kehidupan sehari-hari terutama dalam menyikapi perilaku seks bebas, bagi SMK Muhammadiyah 2 Bantul dari hasil penelitian didapat bahwa pengetahuan tentang perilaku seks bebas meningkat dan dapat merubah kebiasaan siswa SMK kearah yang lebih baik sehingga bapak atau ibu guru dalam hal ini dapat mensosialisasikan penyuluhan mengenai kesehatan reproduksi ke siswa siswi untuk mengurangi resiko akibat yang ditimbulkan dari seks bebas.

\section{RUJUKAN}

1. Sarwono. Psikologi Remaja. Jakarta: PT Raja GrafindoPersada; 2008.

2. Himawan AH. Bukan Salah Tuhan Mengazab. Solo: Tiga Serangkai; 2008.
3. Irwansyah. Pendidikan Jasmani Olahraga dan Kesehatan. Bandung: Grafindo Media Pratama; 2006.

4. Badan Pusat Statistik. Survei Kesehatan Reproduksi Remaja Indonesia 2007.Jakarta: BPS; 2008.

5. Pusat Studi Seksualitas. Riset Aksi Komunitas PKBI DIY. Yogyakarta: PSS; 2008.

6. Dinkes Kabupaten Bantul. Profil Kesehatan Kabupaten Bantul. Bantul: Dinas Kesehatan Kabupaten Bantul: 2010.

7. Soetjiningsih. Buku Ajar: Tumbuh Kembang Remaja dan Permasalahannya. Jakarta: Sagung Seto; 2004.

8. Aryani R, et al. Kesehatan Remaja: Problem dan Solusinya. Jakarta: Salemba Medika; 2010.

9. Notoatmodjo S. Metodologi Penelitian Kesehatan. Jakarta: PT Rineka Cipta; 2010.

10. Notoatmodjo S. Promosi Kesehatan dan IImu Perilaku. Jakarta: PT Rineka Cipta; 2007.

11. Nurhidayah RE. Pendidikan Keperawatan. Medan: USU Press; 2009.

12. Notoatmodjo S. Metodologi Penelitian Kesehatan. Jakarta: PT Rineka Cipta; 2005.

13. Pasaribu, Hotber ER. Perbandingan Penyuluhan Kesehatan Metode Ceramah Tanya Jawab Dengan Penyuluhan Kesehatan Menggunakan Buku Kecacingan Dalam Mencegah Reinfeksi Ascaris lumbricoides Pada Anak Sekolah Dasar, Program Pascasarjana Universitas Diponegoro; 2005.

14. Fayana S. Hubungan Pemberian Pendidikan Seks (Pre Menarche) oleh Orang Tua terhadap Tingkat Pengetahuan Remaja Putri tentang Menarche di SD Muhammadiyah Suronatan. Universitas Muhammadiyah Yogyakarta; 2010.

15. Nisma H. Pengaruh Penyampaian Pendidikan Kesehatan Reproduksi Oleh Kelompok Sebaya (Peer Group) Terhadap Pengetahuan Kesehatan Reproduksi Remaja di SMP Negeri 2 Kasihan Bantul Yogyakarta. Universitas Muhammadiyah Yogyakarta; 2008. 